\title{
A Música de André Abujamra no Cinema Brasileiro
}

\section{Geórgia Cynara Coelho de Souza Santana}

Doutoranda em Meios e Processos Audiovisuais pela Escola de Comunicações e Artes da Universidade de São Paulo (ECA-USP) e docente titular do curso de Cinema e Audiovisual da Universidade Estadual de Goiás (UEG). E-mail: georgia.cynara@usp.br.
Resumo: $\mathrm{O}$ artigo expõe os resultados de uma primeira abordagem sobre a música de André Abujamra no cinema brasileiro, especificamente nos filmes Durval Discos (Anna Muylaert, 2002); Castelo Rá-Tim-Bum, O Filme (Cao Hamburger, 1999) e Bicho de Sete Cabeças (Laís Bodanzky, 2001). Aborda-se o percurso musical do artista no cinema nacional, buscando a relação entre seus projetos fonográficos e suas composições para cinema. Busca-se o exercício da possibilidade de uma análise fílmica a partir da trilha sonora das obras cinematográficas e de conceitos pertinentes ao universo sonoro no audiovisual. Parte-se da análise estética e contextual das obras com trilha sonora assinada pelo artista, de sua biografia e das formulações teóricas relacionadas ao som e à música de cinema, presente nas obras de autores como Gorbman (1987), Chion (1993), Martin (2003), Carrasco (2003), Costa (2008), entre outros.

Palavras-chave: André Abujamra; trilha sonora; cinema brasileiro; música

\section{Title: André Abujamra's Music in Brazilian Cinema}

Abstract: This article presents the results of the first approach to André Abujamra's music in Brazilian cinema, especially in the films Durval Discos (Anna Muylaert, 2002); Castelo Rá-Tim-Bum, O Filme (Cao Hamburger, 1999) and Bicho de Sete Cabeças (Laís Bodansky, 2001). It reveals the musical career of the artist in national cinema, by searching for a relationship between his phonographic projects and musical compositions for movies. It pursues the possibility of a film analysis from considering the movie soundtrack and relevant concepts to the sonic universe in audiovisual. It starts from the aesthetic and contextual analysis of the films whose music pieces are signed by the artist, from his biography, and theoretical formulations related to sound and film music present in the studies of authors such as Gorbman (1987), Chion (1993), Martin (2003), Carrasco (2003), Costa (2008), among others.

Keywords: André Abujamra; soundtrack; Brazilian cinema; music

\section{Introdução}

A combinação entre som e imagem provoca o que Chion (1993) define como ilusão audiovisual: integrado à imagem, o som altera a percepção do espaço diegético, encadeando planos, provendo ritmo, unidade e, por vezes, um caráter realista às cenas. No cinema, o olhar é uma exploração espaço-temporal do que é dado à vista, de forma limitada, pela tela de projeção. A escuta, por sua vez, é a exploração do que é dado (e/ou imposto) ao ouvido, de forma muito menos delimitada que a observação da imagem. Por razões não apenas naturais, como a anatomia do ouvido humano e a natureza do som, mas também devido à ausência 
de uma "cultura da audição", o imposto ao ouvido é difícil de ser editado: na instância sonora sempre há algo que invade e surpreende, portando-se como um meio de condução afetiva e semântica.

O presente trabalho busca perceber, de forma introdutória, as relações músicaimagem-vida do compositor, instrumentista, ator e artista multimídia André Abujamra presente em suas composições para cinema nos últimos 20 anos do cinema brasileiro. Para analisar a relação estabelecida entre a música, os demais elementos sonoros e a imagem em três dos filmes de que Abujamra participa como compositor, investigando como as músicas criadas por ele interferem e aderem à totalidade fílmica, partimos da investigação da existência de traços comuns às obras musicais fonográficas e cinematográficas de André Abujamra, estas compostas para atender a especificidades narrativas diversas, em diferentes contextos e condições de realização.

Buscaram-se evidências dentro e fora dos filmes do corpus de análise que dialogassem com a seguinte questão-problema: em que medida o trânsito de certos elementos harmônicos, melódicos, rítmicos e procedimentos composicionais entre diferentes trilhas musicais para filmes guardam relação com a vida do artista e sua obra discográfica? Para iniciar este processo, foi importante traçar um perfil biográfico do artista, pontuando informações de sua trajetória musical e cinematográfica.

\section{André Abujamra: vida, música, cinema}

Filho do dramaturgo Antônio Abujamra, o cantor, compositor, multiinstrumentista e ator paulistano André Cibelli Abujamra teve no seio familiar seu primeiro contato com a arte. Na década de 1980, ele formou, juntamente com o músico Maurício Pereira, a banda Os Mulheres Negras, que criava canções pop-rock experimentais com letras, visual e performances irreverentes, timbres vocais singulares, instrumentos eletrônicos e uma diversidade de referências pop misturadas em composições bem-humoradas. A dupla, autointitulada "a terceira menor big band do mundo", lançou os discos Música e Ciência (1988), Música Serve Para Isso (1990), separou-se em 1991, teve seus discos relançados em CD em 2005 e retornou à atividade em 2010.

${ }^{1}$ Em entrevista para o site UOL Viagens (2006, disponível em: http://viagem.uol.com.br/famosos/ somparaviagem/2006/07/08/ult3825u9. jhtm , acesso em 13/09/2013), Abujamra conta ao repórter: "[No Egito] Eu estava andadando em um táxi quando escutei uma música que achei bacana. Acabei por comprar a fita do taxista e usei um pedacinho no disco. Até hoje não sei o que é" (ABUJAMRA in UOL Viagens, 2006).

${ }^{2}$ Disponível em: http://www.imdb.com/ name/nm0009494/. Acesso em 19 de novembro de 2012, às $10 \mathrm{~h} 20$.

${ }^{3}$ Disponível em: http://devebe.wordpress. com/2007/05/30/entrevista-com-andreabujamra/. Acesso em: 13/09/2013.
Em 1992, ao regressar do Egito ${ }^{1}$, Abujamra materializou a influência de antigas e novas sonoridades na Karnak. O grupo, conhecido pelas composições simples, engraçadas e arranjos complexos e rica instrumentação, lançou os discos Karnak (1995), Universo Umbigo (1997), Original (1997, voltado para o mercado europeu) e Estamos adorando Tokio (2000).

Em carreira solo, o compositor lançou O Infinito de Pé(2004), Retransformafrikando (2007) e Mafaro (2010), discos que evidenciaram a diversidade de influências do artista, a trajetória em Os Mulheres Negras e no Karnak e a incorporação de sonoridades de várias regiões do mundo em sua obra musical ao longo da carreira.

De acordo com informações do Internet Movies Database (IMDb)2 , entre 1990 e 2012, Abujamra compôs músicas para 31 filmes em longa-metragem. Como compositor, nesse mesmo período, dedicou-se ainda a trilhas sonoras para televisão e publicidade, e também à atuação, tanto na televisão quanto no cinema. $O$ artista foi casado com Anna Muylaert, diretora de filmes cuja composição da trilha ele assina (Durval Discos, por exemplo), ou nos quais ele atua. Em entrevista para o dvblog em 30 de maio de $2007^{3}$, ele conta que quando a conheceu, compôs trilhas musicais para vários curtas-metragens dela e de amigos da faculdade, e assim ingressou nesse universo. Nessa mesma entrevista, o artista fala sobre o papel da trilha sonora musical no cinema, já pensando sobre a articulação desta com os demais elementos sonoros de um filme, e também sobre seu processo composicional: 
É quase $50 \%$, seria $40 \%$ do filme a trilha. Isso somando a música com o som do filme, claro (...). Meu processo criativo de trilha sonora pra cinema é o seguinte: eu ir pra uma praia ou eu andar de metrô, eu andar na rua e começar a imaginar não a música do filme, mas o quê que aquele filme tá trazendo pra mim. Eu só sento no computador e a caneta na orquestra quando eu já sei exatamente como é a trilha (ABUJAMRA in BRASCHE, 2007).

Percebe-se, na fala do artista, a indissociabilidade entre suas experiências de vida e seu processo de criação. Assim, a vivência de Abujamra, uma vez processada e reorganizados seus diversos elementos sob a forma de obras musicais para cinema, pode desempenhar uma série de papéis importantes na narrativa, os quais buscaremos revelar a seguir, a partir do ponto de vista de alguns pensadores sobre o som no cinema.

\section{As possíveis funções da música no cinema}

Ao dizer que "a música serve para conduzir o espectador pelas duras passagens da diegese", Stam (1981: 178) cita o papel da arte musical na promoção de continuidade formal e rítmica entre planos e sequências e na exacerbação de emoções no cinema. Nesse sentido, Onofre alerta que, independentemente de sua presença no cinema, a música tem o poder de provocar tal efeito, a partir do envolvimento com o ouvinte/espectador: "O que não podemos desprezar é que a música, acima de tudo, é um significador de emoção por si só; a emoção ocorre pelo envolvimento do espectador" (ONOFRE in FREIRE, 2009: 39).

Gorbman (1987) observou a presença de diversas características da música nos filmes clássico-narrativos, que têm em Griffith seu precursor: ela pode ser inaudível, se não percebida de maneira consciente pelo espectador, subordinada a imagens e diálogos; pista narrativa, se fornece informações importantes para a compreensão da narrativa pelo espectador - como a indicação de pontos de vista e a caracterização de lugares e personagens. A música também pode promover a unidade de um filme, por meio do desenvolvimento de temas musicais e

${ }^{4}$ Recursos como o mickeymousing - sincronia da música com todos os planos e cada movimento observado na imagem - e o leitmotiv - tema adaptado de acordo com lugares, personagens e situações - foram desenvolvidos e contextualizados ao longo da história da trilha musical para cinema.

\footnotetext{
${ }^{5}$ Martin (2003) considera a divisão dos fenômenos sonoros em duas grandes categorias: a música (não determinada pela ação) e o ruído, que pode ser natural ou humano - onde a voz está contemplada.
} suas variações ${ }^{4}$, e ser invisível, quando a fonte de música é extradiegética, não constando na imagem. Sobre esta última possibilidade, afirma Costa:

A música, via de regra, é a única manifestação sonora com carta branca para estar por sobre as imagens, vindo, na verdade, de lugar algum. Suas ligações com as imagens são tão íntimas que o espectador se esquece de pensar sobre sua localização espacial (COSTA, 2008: 160).

Ao fazer uma retrospectiva histórica da utilização da música em filmes e elaborar propostas de análise fílmica tendo como eixo a linguagem musical, Carrasco observa que o significado da música interage com os de outras linguagens àquela associadas:

Quando a música se associa a outra linguagem, ocorre uma interação significativa. (...) A interação entre as linguagens estabelece novos limites significativos para ambas, ou seja, surge uma nova poética resultante desta combinação, a qual possui convenções próprias, diferentes das que regem uma ou outra individualmente (CARRASCO, 2003: 21).

Desde o surgimento da trilha sonora musical no cinema, predominou a tendência a subordinar a música à imagem, reduzindo o potencial narrativo daquela ao utilizála de forma redundante. Para se chegar às funções da música em filmes, é preciso considerar, pondera Giorgetti (2008), a gama de possibilidades de interpretação, o potencial da música no meio cinematográfico, as concepções estéticas de cada época ou de cada diretor e as exigências específicas de determinado roteiro.

Considerando as três categorias sonoras existentes em um filme - ruídos, diálogos e música ${ }^{5}$ o autor afirma, corroborando Chion (1993), que, salvo casos 
${ }^{6}$ Giorgetti acredita que o uso excessivo da música seja um vício herdado do período silencioso e que o silêncio pode ser, em diversas situações, mais expressivo. raros, a música situa-se em plano inferior às duas outras. A importância decisiva da linguagem musical seria decorrente, então, de sua natureza abstrata, em detrimento da concretude de ruídos e vozes, que, segundo ele, não comportam qualquer outro sentido que não o fornecido com o auxílio da imagem.

A fluidez, a imaterialidade e as consequentes flexibilidade e adaptabilidade da música possibilitam a diversidade de significados, o que faz dela um valioso recurso expressivo no cinema, considera Giorgetti. Devido à dificuldade em precisar funções gerais da música no cinema, o autor sugere dois princípios estéticos gerais, com base em suas experiências como compositor: que a música se limite ao estritamente necessário ${ }^{6}$ e que não se constitua uma obra de arte independente: ela deve se subordinar ao filme, mas não à imagem.

O compositor, claramente embasado por Gorbman (1987), elabora ainda algumas classificações para diferenciar os modos mais comuns de utilização da música no cinema, conforme a importância que ela assume e os resultados a que conduz: música de fundo (background); de preenchimento (destinada a preencher os vazios do filme, como normalmente ocorre nos créditos iniciais e finais); incidental (acompanha ou comenta, sem profundidade, o movimento ou a emoção de uma cena); música-tema (sustentáculo musical do filme, confereIhe unidade); artística (expressiva, aquela cuja supressão prejudica o resultado final do trabalho); música como elemento unificador psico-emocional (aparece em momentos estratégicos, envolvendo o filme num tom psicológico); e música como personagem (quando ela se comporta como agente narrativo).

Assim como Gorbman e Giorgetti, Martin ressalta os papéis básicos desempenhados pela música no cinema, "na medida em que ela é movimento no tempo, como a imagem fílmica" (MARTIN, 2003: 125): o dramático - quando ela se coloca como contraponto psicológico, cria ambientação e/ou ressalta a ação -; e o lírico - quando contribui para a densidade de uma cena, não se limitando a reforçar o que está na imagem. Por isso, propõe-se compreender a análise fílmica - ou seja, a análise da obra cinematográfica, em suas instâncias sonora e imagética - como um possível ponto de partida, valorizando sobretudo a banda sonora em suas relações com a imagem.

\section{Métodos e técnicas de investigação}

Interminável e singular até os limites estabelecidos pela própria obra, o processo de análise fílmica, segundo Aumont e Marie (2004), deve ser adaptado, em método, abrangência e objetivos, aos filmes dos quais o analista se ocupa. Tal "ajuste empírico" torna possível a estratégia de partir da presença da música de Abujamra nos filmes do corpus de análise, articulando-a aos demais elementos sonoros e imagéticos, para que se possa propor uma interpretação que contemple os universos intra e extrafílmicos de cada obra estudada e demonstre as similaridades entre eles e as particularidades de cada um. Vale ressaltar que o destaque dado à música de Abujamra nas análises fílmicas não pressupõe sua autonomia em relação ao conjunto de códigos sonoros que integra, tampouco a autonomia da instância sonora em relação à imagética. Os significados emanados da música nas obras integrantes do corpus somente podem ser concebidos em relação à totalidade fílmica.

Do universo de produções cinematográficas das quais Abujamra participou como compositor, elegemos para este trabalho três longas-metragens brasileiros de ficção como objeto de análise, dentre os filmes com maior facilidade de acesso pelo público, seja por meio da aquisição de DVDs ou arquivos digitais, e nos quais a música possui, conforme nossa hipótese, um papel de destaque, seja em âmbito narrativo, seja pela recorrência de sua utilização: Durval Discos (Anna Muylaert, 2002); Castelo Rá-Tim-Bum, O Filme (Cao Hamburger, 1999) e Bicho de Sete Cabeças (Laís Bodanzky, 2001). 
${ }^{7}$ Não obtivemos acesso apenas ao disco Original (1997), gravado pelo Karnak e direcionado para o mercado fonográfico europeu.
${ }^{8} \mathrm{O}$ conceito de valor agregado proposto por Chion refere-se a um valor expressivo e informativo com o qual o som agrega significado à imagem, de modo a dar a impressão de que tal informação já estava contida nela. Choques, quedas e explosões, por exemplo, "tornam-se mais reais" com a presença do som sincronizado.
Foram estabelecidos ainda os parâmetros fílmicos para a pesquisa, úteis para comparar e reunir os filmes conforme as funções desempenhadas pela música, em cada caso, estruturando a análise e preparando-a para uma posterior etapa de aprofundamento. Dentre eles estão a presença de canção-tema ou de músicatema instrumental, grande elemento de unidade sonora e musical de um filme; integração da trilha musical original (composta e gravada para o filme) com músicas preexistentes (gravadas para outros fins e ressignificada em sua utilização no filme) e outros elementos sonoros (ruídos, diálogos, efeitos), a presença da música exercendo a função de ambientação/background em cenas, a música como elemento sonoro de transição entre sequências, a presença musical sob a forma de leitmotiv; e as características da textura musical integrada ao som do filme (presença de percussão, efeitos, ruídos e vozes - não-palavras - na trilha musical).

Além da análise fílmica, foram realizadas audições da discografia do $\operatorname{artista}^{7}$ e pesquisas por entrevistas concedidas por ele sobre seu processo criativo e sua relação tanto com as experiências vividas em inúmeras viagens pelo mundo quanto de sua discografia com a sua obra musical para cinema (investigação biográfica).

\section{Músicas para ver e ouvir: uma análise introdutória dos filmes escolhidos}

Dentre os filmes em que há contribuições musicais significativas de André Abujamra, Durval Discos (Anna Muylaert, 2002); Castelo Rá-Tim-Bum, O Filme (Cao Hamburger, 1999) e Bicho de Sete Cabeças (Laís Bodanzky, 2001) se destacam, uma vez que, nessas obras, a música contribui para a construção da narrativa e/ou confere unidade e identidade sonora aos filmes, seja por meio de canções preexistentes rearranjadas, seja com canções compostas originalmente para as obras, ou por meio da relação entre as canções e a música instrumental original, da música com o ruído e do resultado narrativo de todo o conjunto som-imagem.

\section{Durval Discos (Anna Muylaert, 2002)}

A passagem da comédia leve ao absurdo é a responsável pela estranheza em Durval Discos. O lado A e o lado B da história, remetidos metonimicamente aos lados de um disco de vinil, são contrastantes entre si e geram gradativamente uma tensão que se apresenta ao espectador como inesperada.

O lado A trata do cotidiano de Durval (Ary França) e sua mãe Carmita (Etty Fraser). Proprietário de uma loja de LPs em São Paulo, Durval exalta a qualidade das músicas dos discos de vinil, em detrimento da qualidade do som e da tecnologia do CD. Kiki (Isabela Guasco), a menina de cinco anos deixada na casa de Durval pela sequestradora disfarçada de empregada Célia (Letícia Sabatella), é a personagem que desencadeia o lado $\mathrm{B}$, rompendo com o aparente equilíbrio inicial. O lado B configura-se em torno do desequilíbrio de Carmita e da inocência de Kiki - para desespero de Durval, o único lúcido e consciente dos fatos.

Em Durval Discos, a ilusão audiovisual de que fala Chion (1993: 11) é a responsável pelo fato de o espectador não notar o exato momento em que o cômico dá lugar ao trágico, tampouco como é o percurso leve e divertido do lado $A$ até os níveis extremos de tensão do lado B. São a trilha sonora e os momentos de silêncio que agregam valor ${ }^{8}$ à imagem.

Ao assistir a qualquer obra cinematográfica, a tendência do espectador é a de centrar a atenção primeiramente nas palavras para, após compreendê-las, interpretar outras linguagens. Trata-se da dificuldade do ouvinte em "editar" o que lhe é imposto ao ouvido. A surpresa e o choque acontecem porque a imagem passa a ser conduzida pela música, e não mais pelo texto, como na analogia de Chion. Durval Discos rompe com o vococentrismo tradicional corrente no meio cinematográfico, uma vez que o sentido do som deixa de ser exclusivamente centrado na voz dos personagens. Em muitos momentos do filme, são privilegiadas 
mais as vozes dos intérpretes das canções que os diálogos. Isto é percebido pela intensidade dada à trilha musical da película, superior em relação aos diálogos dos personagens. No lado $A$, há mais valor agregado pela música e pela reação dos personagens a ela que por suas falas, enquanto no lado $B$ a trilha desconstrutiva e não verbal de composta por André Abujamra é a grande agregadora de valor do filme, indo de encontro à tradição voco e verbocentrista. Pode-se afirmar então esta tradição teria sido "desvirtuada" no lado $A$, uma vez que o verbocentrismo é deslocado para as canções, para ser rompida no lado B.

Em linhas gerais, a trilha musical de Durval Discos é empática. Ela participa das cenas, adaptando-as ao seu ritmo; motiva ações e reações dos personagens; sinaliza novas pistas narrativas na trama - como nos casos da chegada do cavalo à casa e da morte de Elizabeth -; exprime o estado psicológico dos personagens - como a ansiedade de Durval, a despreocupação de Kiki, o desequilíbrio de Carmita -; apresenta e localiza a casa-loja de Durval e provoca alegria, nostalgia e tensão no espectador.

Mesmo na exibição dos créditos (tanto iniciais quanto finais) a música tem um propósito definido: nos iniciais, quando acontece o travelling com o skatista, a regravação de Mestre Jonas feita pelos Mulheres Negras (André Abujamra e Maurício Pereira) assume o caráter de "prenúncio de uma epopeia". Já nos créditos finais, que se iniciam ao som de Pérola Negra, de Luiz Melodia (em vinil), fica clara a derrota do ultrapassado, consagrada com o remix da versão de Mestre Jonas produzido por André Abujamra/Fat Marley (em suporte digital).

Situando a música do filme dentro das características musicais nos filmes de narrativa clássica propostas por Gorbman (1987), pode-se afirmar que a música em Durval Discos é "invisível" quando extra-diegética - o aparato fonte da música não está visível para o público -; é totalmente audível no lado $A$, e parcialmente no lado $B$ - em muitos momentos da primeira parte do filme, a música não só é o centro das atenções (como quando a personagem de Rita Lee entra na loja pedindo o disco de Caetano, ou quando Durval, Carmita e Kiki, fantasiados, dançam ao som de $A$ tonga da mironga do kabulete, de Toquinho e Vinícius de Moraes, ou ainda quando o DJ Théo Werneck aparece na loja para levar os dois discos Tim Maia Racional), como também é previsível - em uma loja de discos de vinil são esperadas canções antigas de LP. Na segunda parte da trama, entretanto, a imprevisibilidade da progressão sonora em função do tempo e a natureza irregular da manutenção da trilha musical - que sutilmente aparece com novos elementos e texturas - promove gradativamente a tensão, até que, sem que o espectador perceba, encontre-se no ápice dela.

A sonorização do filme é composta de som analógico (sinal mecânico de audio transformado em sinal elétrico) e som digital (sinal de audio convertido em informação numérica). O primeiro, que predomina no lado $A$, decorre das músicas fixadas num suporte analógico - o disco de vinil - produzindo um som caracterizado pelo ruído do atrito com a agulha acoplado à música, familiar para quem viveu a época da tecnologia analógica. O segundo, que marca o lado $B$, decorre da trilha musical de Abujamra, manipulável, experimental e densa em texturas, fragmentada, áspera, irregular, atonal e arrítmica.

Alguns temas musicais do lado B - como o do cavalo, o que surge quando a câmera enquadra Elizabeth morta, os temas de tensão - dão unidade ao filme, principalmente quando são mesclados com alguma canção do lado A. É o caso da cena, já no lado B, em que Kiki anda de bicicleta pela casa, ao som da fusão de Imunização Racional com um dos temas originais de tensão, evidenciando a flexibilidade e o potencial narrativo da trilha ao contrapor a inocência da criança ao desespero do protagonista.

Merece destaque o diálogo entre diegese e extra-diegese. No lado A, as canções encontram-se predominantemente no espaço diegético; elas estão na composição das cenas mesmo quando não tocadas (os vinis que participam da cenografia 
também são referências importantes a respeito da história de Durval), e têm origem, na maioria das ocorrências, nos discos de vinil colocados pelo protagonista na vitrola de sua loja. Já no lado $B$, a música instrumental é predominantemente extra-diegética: sua causa está oculta, trata-se da composição original de Abujamra, produzida, mixada e masterizada em seu home studio.

Quando uma mesma música passa de diegética a extra-diegética, há uma alteração de timbres e de espacialidade do som; este é "visivelmente" ampliado e ganha a tela. É como se o mundo do personagem (Durval) fosse ampliado para o mundo do espectador; como se este fosse convidado a participar daquele momento, juntamente com o personagem. Um exemplo é a cena em que Durval dança Back in Bahia, de Gilberto Gil, sozinho em seu quarto.

A música em Durval Discos segue os princípios estéticos propostos por Giorgetti (1998). Todo uso que se faz dela é funcional, evitando excessos e o consequente desgaste. Prova disso é o uso estratégico que se faz do silêncio ao longo da narrativa, o que valoriza não só a cena em que é empregado, como as entradas de música nas cenas seguintes. Apesar do emprego de canções de sucesso da década de 1970, tanto estas como as composições originais têm como função primeira servir à narrativa - mas não se submetendo à imagem. Por coincidência, a trilha empregada é consagrada; mas nem sempre músicas de sucesso são adequadas para compor uma película. Assim, as canções preexistentes servem ao filme, mesmo configurando-se também como um significante independente de emoções.

\section{Bicho de Sete Cabeças (Laís Bodanzky, 2001)}

A densidade das texturas visuais e sonoras da cidade em Bicho de Sete Cabeças evidenciam uma relação íntima do protagonista Neto (Rodrigo Santoro) com os lugares em que se refugia e busca identidade. Tal intimidade com a crueza do ambiente urbano marginal contrasta com a distante relação do personagem com a mãe, Meire (Cássia Kiss) e o pai, Wilson (Othon Bastos) - figura conservadora e autoritária causadora dos traumas de Neto.

Ao descobrir que o filho é usuário de drogas, Wilson o interna à força num hospital psiquiátrico. $O$ desespero e a resistência de Neto são interpretados pelos enfermeiros como um comportamento agressivo típico de dependentes químicos. O processo de enlouquecimento do personagem, separado da família e de si mesmo, é demonstrado pela fotografia, cenografia, montagem, interpretação dos atores e pela utilização não realista do som em várias sequências.

A trilha musical de Bicho de Sete Cabeças participa ativamente da narrativa, imprimindo ritmo à imagem e delimitando espaços internos e externos aos personagens. Em relação aos diálogos e ruídos, a economia na inserção da música evidencia todas as ocorrências de som, de modo que aquela avança ou recua à medida que alguma outra situação sonora torna-se importante. A música não só fornece pistas narrativas ao espectador - seja por meio das letras das canções, das composições atonais de Abujamra associadas à loucura - como conduz a história e promove a continuidade rítmica entre planos e sequências.

A música original de André Abujamra e as canções de Arnaldo Antunes e outros artistas mantém uma relação dialógica e de complementaridade. Ambas são utilizadas com economia em benefício da polifonia audiovisual, de modo a se contrapor aos momentos de menos textura (prevalência do som ambiente em detrimento da fala) e, assim, valorizar sua inserção na trama. A fragmentação da montagem vai ao encontro do concretismo poético de Antunes e do ritmo frenético do ambiente urbano frequentado por Neto, sublinhado pela trilha musical original. Dentro ou fora da diegese, música instrumental, canção e efeitos de silêncio respondem tanto pela intensificação da tensão quanto pela evidência da loucura/ apatia desenvolvida gradativamente por Neto cujo vão esforço de conhecer a si 
mesmo e experimentar a adolescência dá lugar a uma delirante e quase perdida luta contra a apatia provocada por um estado forçado e prolongado de torpor.

A valorização das ocorrências musicais, do silêncio, dos diálogos, da trilha sonora como um todo, segundo Chion (1993), contribui para o valor agregado pelo som à imagem. Sequências de fuga, maus tratos e algazarra tornam-se mais potentes com a presença do som sincronizado e da música, que, assim como a correria dos personagens na imagem, imprime ritmo e agilidade às cenas. A trilha musical original de Abujamra revela toda a violência psicológica de que trata o filme, ainda nos créditos iniciais. O correr de Neto pela cidade, seja depois de uma discussão com o pai, seja tentando fugir da polícia após a pichação de edifícios, tem sua dimensão ampliada pelo predomínio de frequências graves, batidas eletrônicas em alta velocidade e pela presença da guitarra distorcida, cuja melodia sombria remete à relação de Neto com a frieza do ambiente urbano.

As composições de Abujamra oscilam entre o tonalismo e o atonalismo, dada a combinação ou sequenciação de linhas melódicas simples com texturas sonoras densas e de origem não convencional. Sons metálicos e intermitentes sugerem atritos ao mesmo tempo irregulares e constantes e geram desconforto ao espectador cuja audição é culturalmente marcada pela tradição tonal ocidental. Grande pesquisador de sons orientais e world music, Abujamra tem seu trabalho marcado pela experimentação proporcionada pela tecnologia digital, de infinitas possibilidades de manipulação. Essa é a marca sonora dos delírios de Neto e de sua relação com o ambiente do hospital psiquiátrico e as pessoas que ali sobrevivem.

Em algumas sequências em especial essa utilização subjetiva do som e sua integração com a música original se fazem evidentes: quando Neto é capturado após uma tentativa de fuga e levado pelos enfermeiros para a sala de choque, a respiração ofegante, o debater-se e o choro do protagonista constrastam com a impessoalidade dos enfermeiros e do médico - o que é sublinhado pela ausência de música e pela interpretação dos atores. No instante do choque, uma nova gama de sons metálicos e graves da trilha original vêm à tona e acompanham Neto até o final da película, como uma "cicatriz sonora" deixada por toda a violência a que ele havia sido submetido.

Pequenos fragmentos da composição original - desta vez, em frequências agudas - passam, então, a substituir as vozes dos personagens que se relacionam com Neto após sua primeira saída do hospital - o que é percebido pela sincronia entre o movimento das bocas dos personagens e a ocorrência do som distorcido. Isso ocorre apesar de o som ambiente prosseguir audível. Outra situação sonora subjetiva se dá com a audição fragmentada da música que toca no discman de Neto - interrompida sempre que ele tira os fones de ouvido. Por meio de uma audição atenta do filme, é possível perceber o processo de desumanização do personagem, que vai se tornando mais um ser apático a vagar pelo hospital.

${ }^{9}$ Para ambientar o lugar em que Neto encontra os amigos e caracterizar esse universo adolescente urbano, são utilizadas canções de rap (O Caminho das Pedras - banda Zona Proibida) e punk rock nacional (Satélites - banda Infierno).
As canções de Bicho de Sete Cabeças referem-se aos delírios de Neto, aos lugares frequentados por ele, às companhias de que desfruta ${ }^{9}$. Em sua maioria composições de Arnaldo Antunes, essas peças musicais surgem em momentoschave do filme e convidam o espectador a uma experiência sinestésica. $\mathrm{Na}$ ocasião em que Neto está na casa de Leninha, mulher que conhecera num bar, no momento em que os dois personagens começam a trocar olhares a fotografia de cores quentes une-se à canção O Seu Olhar (de Paulo Tatit e Arnaldo Antunes) para revelar a visão subjetiva de Neto, que volta de ônibus para casa mirando o céu, entrecortada pelas lembranças daquela noite de amor: "O seu olhar lá fora / O seu olhar no céu / O seu olhar demora / O seu olhar no meu".

A balada, em mi maior, é marcada pela presença oitavada da voz masculina extremamente grave de Arnaldo Antunes e a feminina extremamente aguda de Nina Becker. Esse dueto revela a distância entre Neto e Leninha, cuja relação, apesar daquele contato, não pode ser duradoura. Curiosamente, a voz feminina, 
quase infantil, remete ao Neto adolescente, enquanto a masculina se remete à experiência de Leninha, mulher madura que passa a habitar os pensamentos do rapaz a partir de então. A distância de timbres e texturas entre as vozes também é expressa poeticamente na imagem, por meio dos fios que alta tensão que correm paralelos na visão subjetiva de Neto, da janela do ônibus em movimento.

Um dos momentos mais marcantes da canção no filme, no entanto, ocorre quando um dos internos mais velhos do hospital diz: "A gente até precisa fingir que é louco sendo louco, fingir que é poeta sendo poeta". Ele convida Neto a ler as palavras gravadas na parede, que correspondem à letra da canção $O$ Buraco do Espelho (Edgard Scandurra e Arnaldo Antunes). A câmera passeia pelas palavras, enquanto a música, "recitada" por Antunes num ritmo compatível com o movimento da imagem, revela a prisão definitiva de Neto no universo da loucura e o perigo iminente da morte: "o buraco do espelho está fechado / agora eu tenho que ficar aqui / com um olho aberto, outro acordado / no lado de lá onde eu caí". A entoação grave de Antunes na canção, acompanhada do dedilhado da guitarra em uma linha melódica distorcida, revela-se uma extensão da fala do personagem. As imagens igualmente distorcidas da parede misturam-se às imagens fixas e em preto e branco da mãe de Neto, em casa, sofrendo com a ausência do filho.

Depois de voltar para casa carregando suas marcas, o personagem é novamente internado devido ao comportamento agressivo. $\mathrm{O}$ som e sua espacialidade são importantes para externar a sensação de prisão de Neto na solitária, cubículo escuro para onde é levado". Da segunda vez que ele é preso na solitária, tenta o suicídio incendiando o lugar. Quando a porta se abre e Neto, enfim, consegue respirar, pode-se ouvir, então, a canção que dá nome ao filme - Bicho de Sete Cabeças (Zé Ramalho, Geraldo Azevedo e Renato Rocha), interpretada por Zeca Baleiro-, que marca o renascimento do personagem, a possibilidade de recomeço, apesar das cicatrizes e da lembrança negativa do pai: "Não dá pé / Não tem pé, nem cabeça / Não tem ninguém que mereça / Não tem coração que esqueça / Não tem jeito mesmo / Não tem dó no peito / Não tem nem talvez ter feito / O que você me fez desapareça / Cresça e desapareça... ". A canção embala a saída de Neto do hospício, paralela à cena do pai que, em lágrimas, lê a carta do filho - a mesma da cena inicial do filme. A sequência descendente de notas do refrão, repetida e superposta às estrofes da canção, conclui o ciclo narrativo com o lirismo e a melancolia de uma resignada aceitação do destino.

Especialmente em se tratando da canção-tema - que só é ouvida ao final do filme -, a música configura-se também como um significante independente de emoções, uma vez que o espectador-ouvinte nutre sentimentos e interpretações prévias em relação à canção, ressignificada por Laís Bodansky para finalidades narrativas específicas.

\section{Castelo Rá-Tim-Bim, O Filme (Cao Hamburger, 1999)}

Em Castelo Rá-Tim-Bum, O Filme, a música-tema original desdobra-se em variações orquestrais para ambientar a história da tradicional família de bruxos Stradivarius, que mora em um castelo na cidade de São Paulo. Morgana (Rosi Campos), Victor (Sérgio Mamberti) e seu sobrinho e aprendiz Antonino/Nino (Diegho Kozievitch) aguardam o alinhamento dos planetas, evento celeste que fortalece os poderes dos feiticeiros. Às vésperas desse acontecimento, Losângela (Marieta Severo), banida da família Stradivarius por suas maldades, volta à cidade e, com a ajuda de Dr. Abobrinha (Pascoal da Conceição) e seu capanga Rato (Matheus Nachtergaele), rouba o livro de Morgana, fazendo com que o casal de bruxos perca seus poderes. Cabe a Nino começar seu próprio livro e salvar a família, recuperando o livro de Morgana, os poderes de seus tios e o castelo tomado por Losângela.

A obra conserva as características musicais e o didatismo presentes na trilha sonora da série televisiva na qual se baseia, Castelo Rá-Tim-Bum, criada por Flávio Souza e Cao Hamburguer (diretor do filme) e exibida na TV Cultura entre 
1994 e 1997. A trilha musical original assinada por André Abujamra (que faz figuração no filme, como o recepcionista do hotel) e Lulu Camargo pode ser ouvida durante quase a totalidade da obra, como frequentemente ocorre em desenhos animados e seriados infantis. Altamente codificada, ela apresenta frequências agudas e ritmo veloz em momentos de alegria - como quando as crianças da vizinhança empinam pipa perto do castelo ou quando elas brincam com Nino relevando o fato de ele não ser uma criança comum -; acompanha os momentos de medo e mistério com notas graves e ritmo lento - como quando Losângela chega à cidade e alia-se ao Dr. Abobrinha para tomar o castelo de Victor e Morgana; apresenta as personagens, demarcando quais são os vilões e quais os heróis; pontua cada movimento dos personagens em situações específicas (mickeymousing, quando Nino tenta abrir o livro de Morgana, fazendo cócegas na capa); imprime dinâmica às passagens de tempo (quando as crianças brincam na rua) e às ações dos personagens - acrescidas de ritmos eletrônicos quando Dr. Abobrinha e Losângela são expulsos do castelo - e sofre diversas variações de textura e "humor" no decorrer da narrativa (leitmotiv), transformando-se, por vezes, de música instrumental em canção e vice-versa.

Na canção, o encadeamento silábico é utilizado para simular idiomas como o latim e o alemão, misturando-os a palavras em português ou de origem indígena, remetendo à realeza e às origens tradicionais da família milenar de bruxos em convivência com a pluralidade cultural brasileira. A Ópera Arepó composta por Abujamra para o filme, já revela, no título, os efeitos das combinações silábicas, as inversões de palavras (de ópera para "arepó", de Castelo Rá-Tim-Bum para "mubmitar oletsac") e a referência à erudição da família de Nino: "stradivarius dras trubufu! / vrais angu! / stradivarius dras trubufu! / vrais angu! / macacos me mordam / das micus leão! / duns livrum abertum / caído do chão! / (...) mubmitar oletsac / mubmitar oletsac". Trechos cantados da música são ouvidos quando a câmera apresenta o castelo e a família de bruxos; no momento em que Nino tem a ideia de salvar seus tios do feitiço de Losângela usando a pedra preta de Morgana; quando ele se concentra para pegar a pedra dentro do espelho e atinge seu objetivo. Estrofe e refrão da canção surgem quando Morgana e Victor, transformados em marionetes por Losângela, cantam, como em um espetáculo, para despistar o Dr. Abobrinha, enquanto a amiga de Nino escreve o feitiço no livro de Morgana para que os poderes de Losângela sejam eliminados.

No entanto, durante quase todo o filme, a trilha musical predominantemente orquestral está em segundo ou terceiro plano, dada a importância da narração em voz over de Nino (que abre e fecha o filme) e dos diálogos entre personagens estilizados; a necessidade de clareza narrativa não apenas por meio da linguagem cinematográfica, mas sobretudo da palavra - cujo didatismo provavelmente supõe uma melhor compreensão pelo público infantil -; e todas as demandas interpretativas, de entonação e figurino de uma narrativa fantasiosa.

${ }^{10} \mathrm{O}$ papel de ornamento exercido pela música no filme é destacado nos momentos de realização dos feitiços - quando contextualiza os efeitos sonoros decorrentes da ação dos bruxos e suas vozes reverberadas -, a cada vez que o livro de Morgana é aberto (tom religioso) e também sob uma forma de "pontuação", como quando alguns personagens proferem seus jargões ("Raios e trovões", de Victor Stradivarius, "Este castelo será meu", do Dr. Abobrinha, ou quando Losângela revela seu rosto para a câmera, gritando o próprio nome e repetindo-o).
Muitas vozes diferentes de personagens humanos e não humanos, principais e secundários, convivem com diversos efeitos sonoros decorrentes tanto dos feitiços realizados pelos bruxos dentro do castelo quanto das estratégias narrativas para a sinalização da chegada de novas informações (como o ruído da gralha, que pontua a chegada e a localização da vilã Losângela na cidade). Assim, diálogos e efeitos sonoros predominam sobre a música em várias ocasiões e, em decorrência das múltiplas ênfases dadas ao caráter fantástico da narrativa tanto em âmbito imagético quanto sonoro não-musical, os papéis de "ornamento"10 ou "música invisível" sobrepõemse à função de pista narrativa (Gorbman, 1987) exercida pela trilha musical.

A música adquire maior importância apenas no ensaio do minueto para o baile do alinhamento dos planetas e no baile propriamente. Nestes dois momentos, a música vai para o primeiro plano sonoro, sob a forma de uma valsa alegre e densa em texturas (instrumentos de sopro e cordas predominam), com poucas interferências vocais e de 
efeitos. No ensaio, apenas Nino e sua tia Morgana dançam no salão vazio; no baile, o lugar aparece repleto de personagens. A trilha musical recua e desaparece, no ensaio, quando Nino lembra que precisa escrever seu livro até o dia seguinte, quando seu tio Victor voltar; no baile, ela recua quando a voz over de Nino reaparece para finalizar a história e quando ele testa seus novos poderes de feiticeiro - momento em que os efeitos sonoros ascendem ao primeiro plano -, desaparecendo quando a câmera mostra Nino escrevendo as palavras finais em seu livro.

Com pouco espaço na trama, os efeitos de silêncio ou de grande diminuição de textura sonora (com a ausência de música e/ou efeitos) ocorrem apenas em momentos que antecedem falas cruciais para a compreensão da história. Isso acontece, por exemplo, para criar expectativa no momento em que Nino abre o livro para escrever, mas não sabe por onde começar; ou quando ele vai ao encontro dos tios transformados em marionetes, que recomendam que ele fuja; ou para enfatizar o estranhamento da família de um dos seus amigos quando o pequeno bruxo surge para tomar o café da manhã. A música e os efeitos também estão ausentes quando Losângela constata sua vitória sobre os bruxos-marionetes, no momento em que as crianças elaboram o plano para tirar os poderes da feiticeira má e quando Victor, no final do filme, pede para ver o livro de Nino.

Além da Ópera Arepó presente ao longo do filme, outras canções aparecem nos créditos finais, com arranjos eletrônicos e urbanos (rap) substituindo ou se acoplando à orquestração em melodias já ouvidas no decorrer da narrativa e letras que lembram situações e emoções vividas pelos personagens. Estranho não, diferente, gravada pelo Karnak para o filme, mostra o conflito de Nino diante de sua condição de aprendiz de feiticeiro, diferente das outras crianças, unindo a orquestração que remete às origens de Nino ao rap familiar ao repertório infantil no espaço urbano: "Eu disse pra minha tia: "Tia eu quero ser igual" / Ela achou meio esquisito, mas eu não falei por mal/ Ser igual aos outros garotos / Porque as vezes a magia, me faz sentir tão só". Na canção Amigos normais, também gravada pelo Karnak, o mesmo tema é abordado, celebrando as amizades feitas por Nino, que não se sente mais sozinho: "Um amigo tem com quem conversar / Um amigo sempre é bom, muito bom / Quando o amigo vem é pra aproximar diferentes corações". Aqui, André Abujamra alia suas composições originais para o filme a sua banda Karnak, cuja discografia é marcada pela densidade de texturas, simplicidade das letras e pelo uso criativo dos recursos eletrônicos em misturas musicais não convencionais.

\section{Considerações finais}

As trilhas musicais de André Abujamra para os filmes analisados guardam aproximações sonoras significativas com seus projetos musicais fora da área cinematográfica - destaque para as bandas Os Mulheres Negras, Karnak e para os discos-solo do artista. Tal como na Ópera Arepó, canção-tema de Castelo-Rá-TimBum, O Filme, o humor decorrente das combinações silábicas é uma característica das composições de Abujamra, na maior parte de seus discos. A comicidade encontra-se, em geral, na simplicidade das letras, no encadeamento das palavras, na métrica (responsável pelo ritmo da enunciação) e nos arranjos musicais que aglutinam esses arranjos verbais, como na canção Mediócritas, do Karnak (disco Estamos adorando Tokio, 2000): “Ninguém quer te ver feliz / Todo mundo quer que você quebre o nariz / Ninguém quer te ver contente / Todo mundo quer que você quebre os dentes"' (ABUJAMRA in KARNAK, 2000). Igualmente, o recurso de mistura de palavras de idiomas diferentes também é encontrado nas discografias de Abujamra. Em Estamos adorando Tokio, canção que dá nome ao disco do Karnak lançado em 2000, temos o espanhol, o inglês e o português na mesma estrofe, mistura que revela a identidade multifacetada do grupo: "Mira los karnako, me gusta Tokio / When you get out please take a passaporto / Mira los karnako, estamos adorando Tokio". 
A versão de uma música preexistente foi rearranjada por Abujamra e tornou-se a canção-tema Durval Discos. Mestre Jonas, composta por Sá, Rodrix e Guarabyra, ganhou não apenas uma, mas duas versões do compositor: uma interpretada pelos Mulheres Negras, na voz de Maurício Pereira, com ares de surf music; e outra por Fat Marley, personagem de Abujamra no filme (e fora dele), esta uma "versão da versão" dos Mulheres Negras, eletrônica, com beat acelerado e inserções de falas dos personagens. As duas versões são simétricas em suas inserções no filme: a primeira, dos Mulheres Negras, abre Durval Discos, anunciando de início a metáfora bíblica de Jonas, que vive preso na baleia, vinculada ao protagonista Durval, que vive preso no passado, na ligação infantil com a mãe Carmita e na paixão por discos de vinil. A segunda versão de Mestre Jonas, por sua vez, aparece depois de metade dos créditos finais: o remix eletrônico de Fat Marley coroa a derrocada do passado (e do vinil, do som analógico) diante das múltiplas possibilidades do presente (e do som digital).

Algo que chama a atenção nas composições de Abujamra para esses filmes é a capacidade do artista em integrar sua música aos outros elementos sonoros da narrativa fílmica - músicas preexistentes, ruídos, diálogos entre personagens e efeitos sonoros. Isso acontece de forma menos previsível nos filmes Durval Discos (Anna Muylaert, 2002) e Bicho de Sete Cabeças (Laís Bodanzky, 2001). Algumas composições originais para esses filmes, se ouvidas fora do contexto, podem parecer muito sutis; no entanto, combinadas a outros elementos sonoros, têm papel fundamental na ligação deles entre si e com a imagem.

Em Durval Discos, a trilha sonora musical é percebida em dois momentos análogos aos lados de um disco de vinil: no lado $A$, temos um festival de músicas brasileiras, canções eternizadas nas vozes de Tim Maia (Que Beleza), Elis Regina (Madalena), Sá, Rodrix e Guarabyra (Mestre Jonas, que aparece em sua gravação original, além das outras versões elaboradas para o filme), Gilberto Gil (Maracatu Atômico, Back in Bahia), Toquinho e Vinícius (A Tonga da Mironga do Kabuletê), Novos Baianos (Besta é tu) - além das referências visuais (capas de discos, figurino e caracterização de Durval). No lado B, com o conflito instalado na narrativa, surge então a trilha musical original de Abujamra, a princípio discretamente, em plano sonoro de fundo, em composição tonal, harmônica e melódica com as canções preexistentes já apresentadas no "lado A", elevando-se gradualmente até o clímax, quando a música original vai para o primeiro plano sonoro, sobrepondo-se inclusive aos diálogos. Nesse momento, as vozes que se unem em cantos, gritos e percussão lembram a ideia de ritual empregada na trilha composta pelo artista para um outro filme, Um Copo de Cólera (Aluízio Abranches, 1999).

Assim como em Durval Discos, várias canções, desta vez de Arnaldo Antunes, compõem a trilha musical de Bicho de Sete Cabeças: O Buraco do Espelho, Fora de Si, O Seu Olhar e outras composições de Antunes parecem se conectar ao filme com o suporte das composições originais de Abujamra, que utiliza o eletrônico, o atonal, diversas alturas e texturas sonoras e até falas do próprio filme tratadas de forma distinta dos diálogos para dar ao conjunto sonoro coesão e organicidade. A voz grave de Antunes, combinada à inesperada "sujeira sonora" das composições de Abujamra entram em consonância com os ruídos ensurdecedores da metrópole e das lembranças do protagonista Neto (Rodrigo Santoro), e todo esse conjunto entra em conexão com a "sujeira da imagem", o cinza da cidade, os muros pichados, a poluição, o cotidiano automático no seio familiar. Toda essa poluição sonora e visual clama por respiração por meio da canção preexistente e homônima Bicho de Sete Cabeças (composta por Geraldo Azevedo em parceria com Zé Ramalho), em versão cantada por Zeca Baleiro.

Já em Castelo Rá-Tim-Bum, O Filme, conforme analisado, a música de Abujamra segue as convenções já consagradas na série televisiva homônima, o que acarreta a previsibilidade das composições em sua relação eminentemente ilustrativa com 
os diálogos e efeitos sonoros empregados largamente na narrativa fantástica. Também aqui, as canções (originais, gravadas pelo Karnak) dialogam com o filme, mas de maneira ornamental, reforçando o que já se encontra na trama sob a forma de linguagem cinematográfica.

Nos últimos 20 anos, Abujamra se sobressaiu com sua contribuição musical ao cinema brasileiro, sendo considerado no meio cinematográfico nacional um "trilheiro profissional", ou seja, um compositor especializado em trilhas sonoras musicais para cinema. Antes disso, porém, a partir da década de 1980, o artista já atuava nos Mulheres Negras, depois do Karnak e então em carreira solo. Atualmente, Abujamra administra o retorno destes dois importantes grupos com seu trabalho discográfico solo, trilhas musicais para filmes e televisão.

Iniciou-se, neste trabalho, o caminho para estabelecer as aproximações entre as linguagens musical e cinematográfica na carreira multifocal de Abujamra. As análises de Durval Discos, Bicho de Sete Cabeças e Castelo Rá-Tim-Bum, O Filme conduzem à confirmação das hipóteses de que as obras musicais compostas pelo artista para o cinema brasileiro atendem às especificidades narrativas de cada filme, ao mesmo tempo compartilhando entre si determinados elementos harmônicos, melódicos e procedimentos composicionais; de que, nesse sentido, torna-se possível a percepção de uma assinatura musical cinematográfica do artista, marcada pela diversidade de referências musicais e ao mesmo tempo pela síntese que o artista logra fazer delas; e, finalmente, de que é possível apurar a prática da análise fílmica por meio de um estudo mais aprofundado da banda sonora cinematográfica e de suas relações com as imagens às quais ela se articula, potencializando a híbrida musicalidade da polifonia audiovisual.

Cabe verificar, em etapas posteriores do trabalho, se o mesmo ocorre em outras obras cinematográficas com composições do artista e o quanto os aspectos extrafílmicos - o processo criativo de Abujamra, as diversas funções exercidas por ele em filmes, as parcerias do artista com músicos, produtores musicais e estúdios de gravação, a recorrência da trilha musical do artista em mais de um filme de um mesmo diretor, seu diálogo com a direção em cada caso - interferem no resultado das narrativas audiovisuais nas quais ele atua.

A análise de filmes brasileiros com composições musicais de Abujamra e da relação dessas composições com o processo criativo e a vida de um dos artistas mais ativos, inventivos e multifacetados da música brasileira para cinema ora em continuidade contribui para a elevação da importância da música brasileira no cinema; para o entendimento de que o significado da música também está na relação entre o que se ouve e o que se vê; e para a identificação das estratégias narrativas da linguagem musical no contexto das duas últimas décadas do cinema brasileiro.

\section{Referências Bibliográfia}

AUMONT, Jacques; MARIE, Michel. A Análise do Filme. Lisboa: Edições Texto \& Grafia, 2004.

BRASCHE, Denis Von. Entrevista com André Abujamra. Disponível em: <http:// devebe.wordpress.com/2007/05/30/entrevista-com-andre-abujamra/>. Acesso em: 13 setembro 2013.

CARRASCO, Claudiney. Sygkhronos: a formação da poética musical do cinema. São Paulo: Via Lettera: Fapesp, 2003.

CAZNOK, Yara B. Música: entre o audível e o visível. São Paulo: Unesp, 2003. 
CHION, Michel. La audiovisión - Introducción a un análisis con-junto de la imagen y el sonido. Barcelona: Ediciones Paidós, 1993.

COSTA, Fernando Morais. O som no cinema brasileiro. Rio de Janeiro: 7Letras, 2008.

FREIRE, Rafael de Luna (org). Nas Trilhas do Cinema Brasileiro. Rio de Janeiro: Tela Brasilis, 2009.

GIORGETTI, Mauro. Da natureza e possíveis funções da Música no Cinema. Disponível em: <http://www.mnemocine.com.br/index.php/cinema-categoria/29somcinema/161-funcoes-musica-cinema> . Acesso em 19 julho 2014.

GORBMAN, Claudia. Unheard Melodies: Narrative Film Music. Bloomington: Indiana University Press, 1987.

IMDB. André Abujamra. Disponível em: <http://www.imdb.com/name/ nm0009494/>. Acesso em: 19 novembro 2012.

MARTIN, Marcel. A linguagem cinematográfica. São Paulo: Brasiliense, 2003.

STAM, Robert. O Espetáculo Interrompido. Rio de Janeiro: Paz e Terra, 1981.

UOL VIAGENS. André Abujamra: Em sua trilha para viagem, músico e produtor coloca sons egípcios e Hermes Aquino. Disponível em: <http://viagem.uol.com.

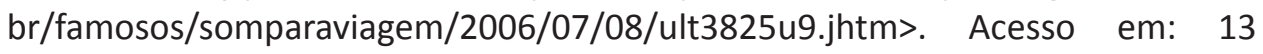
setembro 2013. 